\title{
Extreme Wind Effects on Roof Structures of Low Rise Buildings
}

\author{
Kesan Angin Ekstrem kepada Struktur Bumbung Bangunan Rendah \\ Nuur Zuleikha Baha \& Siti Aminah Osman*
}

\begin{abstract}
Roof structure should be properly designed to withstand any applied loads and stress. The distribution of the load on the roof system can be divided into three types which are dead load (roof structure), live load and wind load (stress due to dynamic interference). Wind load is the main stress experienced by the roof. The stability of the roof depends on its support such as roof frame, pillars, walls, beams and foundations. The aim of this study is to determine the maximum pressure distribution on the roof when been subjected to high wind load caused by extreme wind speed through computer simulation. This maximum pressure might cause failure in the roof structure. In this study, a series of parametric studies were carried out which include different type of roof shape, different angle of roof pitch and different angle of wind attack. Through simulation results, it was found that the hip and gable roof type has experienced the biggest failure for wind in direction of $0^{\circ}$. Besides that, it is evident from the results that the hip roof type with an angle of $10^{\circ}$ is more practical and has less damage. From these simulation results, the most critical areas with high pressure distribution can be identified.
\end{abstract}

Keywords: Extreme wind; pressure distribution; computer simulation; roof structure; turbulent flow k- $\varepsilon$

ABSTRAK

Struktur bumbung yang dibina mestilah kukuh dan berupaya menanggung beban serta tegasan yang dikenakan. Pengagihan beban ke atas sistem bumbung boleh dibahagikan kepada tiga jenis beban iaitu beban mati (struktur bumbung), beban hidup dan beban angin (tegasan yang diakibatkan oleh gangguan dinamik). Beban angin merupakan tegasan utama yang dialami oleh bumbung. Kestabilan bumbung bergantung kepada bahagian-bahagian penyokongnya seperti kerangka bumbung, tiang, dinding atau tembok, rasuk dan asas bangunan. Kajian ini bertujuan untuk menentukan taburan tekanan maksimum di atas bumbung apabila dikenakan beban angin yang tinggi akibat angin ekstrim melalui simulasi berkomputer. Tekanan tinggi yang terhasil ini akan menyebabkan kegagalan pada struktur bumbung. Dalam kajian ini, beberapa siri parameter kajian telah dijalankan termasukjenis bentuk bumbung yang berlainan, sudut kecerunan bumbung yang berlainan dan arah tindakan angin yang berbeza. Melalui keputusan simulasi, didapati jenis bumbung hip dan gabel mengalami kegagalan terbesar pada arah tindakan angin $0^{\circ}$. Selain itu, keputusan kajian membuktikan bahawa jenis bumbung hip bersudut $10^{\circ}$ adalah lebih praktikal dan kurang mengalami kerosakan. Dari hasil keputusan simulasi, kawasan yang paling kritikal dengan taburan tekanan yang tinggi dapat dikenal pasti.

Kata kunci: Angin ekstrem; taburan tekanan; simulasi berkomputer; strktur bumbung; aliran gelora k- $\varepsilon$

\section{INTRODUCTION}

Roof is a part of important structure in the construction of a building. The roof acts as internal shielding structure of the building from the scorching heat of the sun, rainy, extreme wind and others. Without a good design, the roof structure may lead the internal structures to severely damage thus increasing the cost of repairs. The roof structure consists of trusses, roof sheathing and its connections. The roof is built to support three types of loading namely dead loads, live loads and also wind loads. In this study, only the wind loads will be considered.

In Malaysia, the occurrence of wind extreme with speed of range $17-39 \mathrm{~m} / \mathrm{s}$ is mostly due to hurricane and thunderstorms which are usually followed by rains. Most of the affected areas are concentrated to rural areas and suburban areas where the structures are mainly from singlefamily residential buildings and small industry buildings (Rahaman 2007). Failure and damage from the disaster caused huge economic losses, in which the government needs to spend millions of ringgit to reconstruct and repair. Moreover, failure of this structure is mostly on the roof system that caused by high local suctions and large pressure fluctuations around the roof periphery and protruding (Ramli et al. 2010). The main objective of this study is to determine the maximum pressure distribution on the roof when subjected to high wind load caused by extreme wind. The pressure distribution can be obtained through a computer simulation using Computational Fluid Dynamics method. A three dimensional of single storey model with different roof shapes is simulated and compared, finally the most practical roof pitch and type can been identified. 


\section{SIMULATION METHOD}

For the purpose of this study, three dimensional (3D) finite element software COMSOL Multiphysics was used. The residential building was simulated by employing the principles of Computational Fluid Dynamics (CFD) in turbulent flow $k-\varepsilon$ epsilon. The turbulent flow, $k-\varepsilon$ is used for simulating the building model at high Reynolds number. Incompressible flow is applied as the physics interface in stationary analysis in which the variables do not change over time. This model has correlation in terms of turbulence kinetic energy, $k$ in the flow and the dissipation rate of turbulence kinetic energy, $\varepsilon$.

The model of single storey house from Xiao and Yuan (2013) was selected in this study. The building model of dimension 0.9 m length (L), $0.4 \mathrm{~m}$ width (B) and $0.225 \mathrm{~m}$ height $(\mathrm{H})$ was developed in wind tunnel tests with working section of $15 \mathrm{~m}$ length (L), $3 \mathrm{~m}$ width (B) and $2.5 \mathrm{~m}$ height (H) as shown in Figure 1 (a). The extreme wind of $40 \mathrm{~m} / \mathrm{s}$ (based on the highest wind speed of $39 \mathrm{~m} / \mathrm{s}$ was recorded at Ipoh, Perak) is used to simulate the model over suburban terrain (Nur Zuleikha 2015). The building model as shown in Figure 1 (b) have two different types of roof shapes such as hip and gable design with different roof pitch which are of $10^{\circ}$ and $25^{\circ}$. These roof pitch were selected as it were always used for most of houses in Malaysia. Both of the models were simulated to investigate the effects of wind extreme on the roof system as shown in Figure 1.

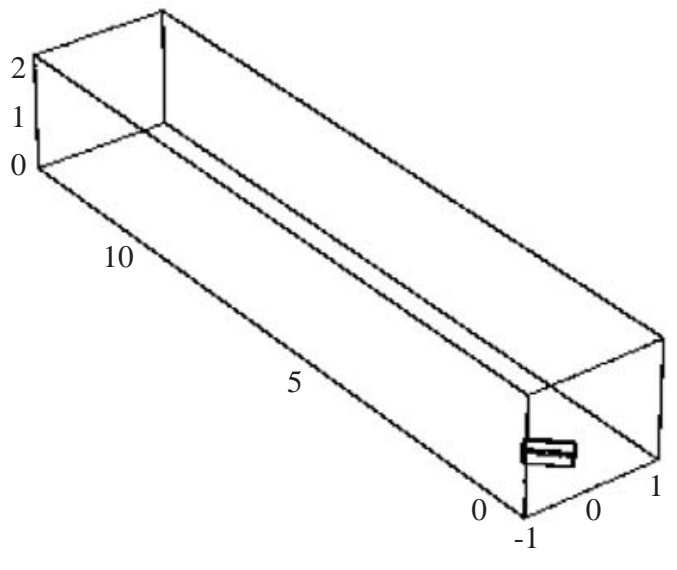

(a) Wind tunnel

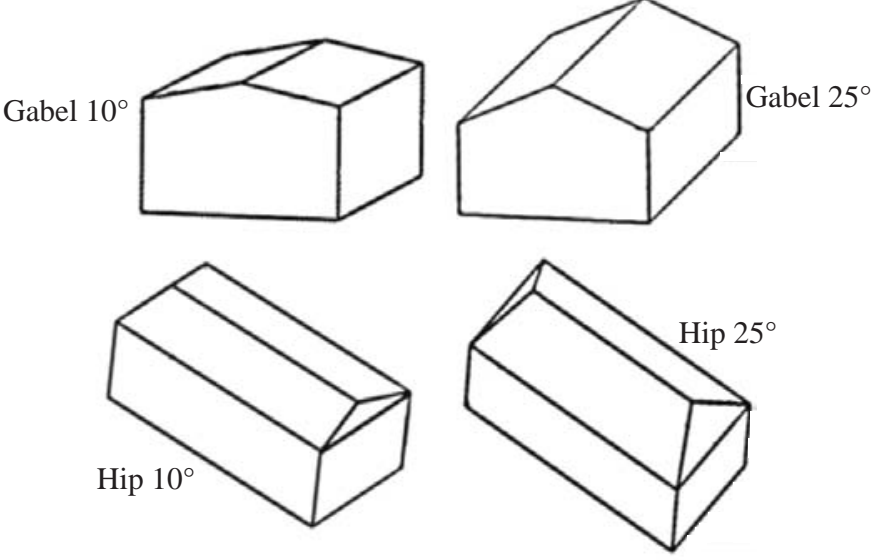

(b) Building model

FIGURE 1. Schematic view of models

In this simulation, all the initial values for velocity and pressure are set to zero. For the boundary conditions, the wall functions were applied to the ground surface. Meanwhile for all wall boundaries, slip boundary condition were selected. The profile velocity of $40 \mathrm{~m} / \mathrm{s}$ at $10 \mathrm{~m}$ height was imposed at the inlet condition as shown in Figure 2. The power law of equation for velocity was used to compute this profile. This velocity equation profile is defined as follows (Simiu \& Scanlan 1978, Manwell et al. 2002):

$$
U\left(z_{g 1}\right)=U\left(z_{g 2}\right)\left(\frac{z_{g 1}}{z_{g 2}}\right)^{\alpha}
$$

where $\alpha$ is the exponent dependent on terrain roughness (Power law of exponent), $U\left(z_{q 1}\right)$ is the basic or reference wind speed at height of $z_{q 1}(\mathrm{~m} / \mathrm{s}), U\left(z_{q 2}\right)$ is the wind speed of boundary layer at height of $z_{g 1}(\mathrm{~m} / \mathrm{s})$ and $z_{g 1}$ or $z_{g 2}$ is the height from ground level (m). Besides, the simulation used 310,198 elements of meshing due to the limitations of computer processor. The schematic view of meshing for the wind tunnel is shown in Figure 3.

\section{RESULTS AND DISCUSSION}

The simulation results of pressure were obtained in the forms of contours. The values of pressure were calculated in the form of a non-dimensional pressure coefficient, $C_{p}$ defined as follows (Osman et al. 2004):

$$
C_{p}=\frac{p-p_{0}}{0.5 \rho U^{2}}
$$

where $p$ is the pressure measured at the surface model, $p_{\text {o }}$ is the static pressure at the reference height or referring to Osman et al. (2006) $p_{\mathrm{o}}$ is the wind pressure before distraction normally set up as zero to get the difference of pressure at certain point in the domain (Selvam 1992), $\rho$ is the density of air and $U$ is the mean wind speed at reference height or before distraction.

\section{GABLE ROOF}

Figure 4(a) and (b) shows the pressure distribution on the gable roof pitch $10^{\circ}$ and $25^{\circ}$. When the wind direction is normal to the roof ridge, both of the roofs experience the 


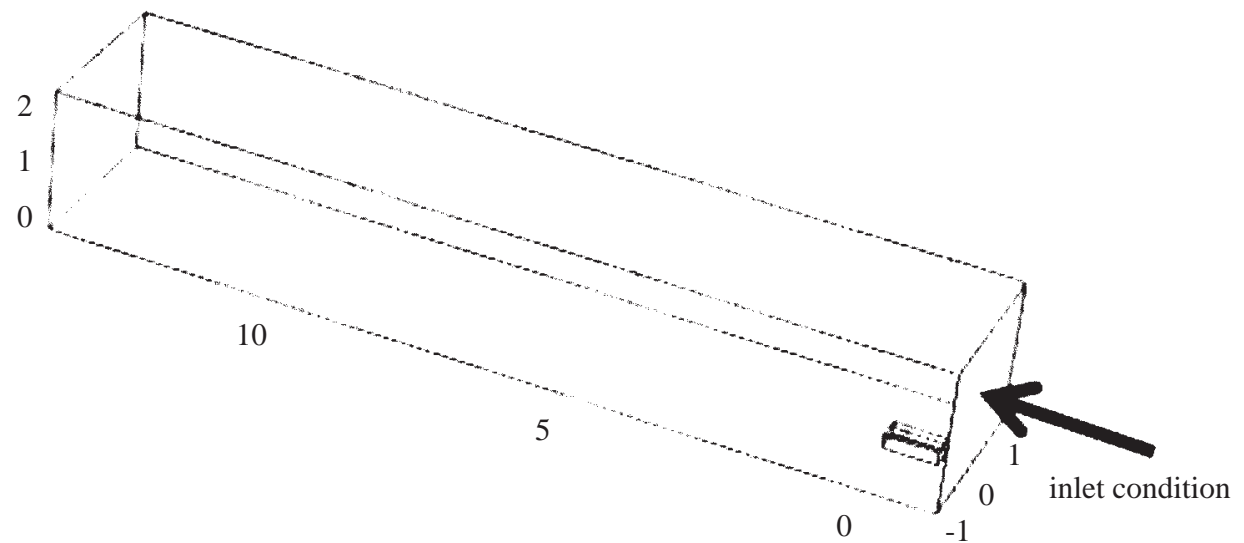

FIGURE 2. Schematic view of inlet condition for wind flow

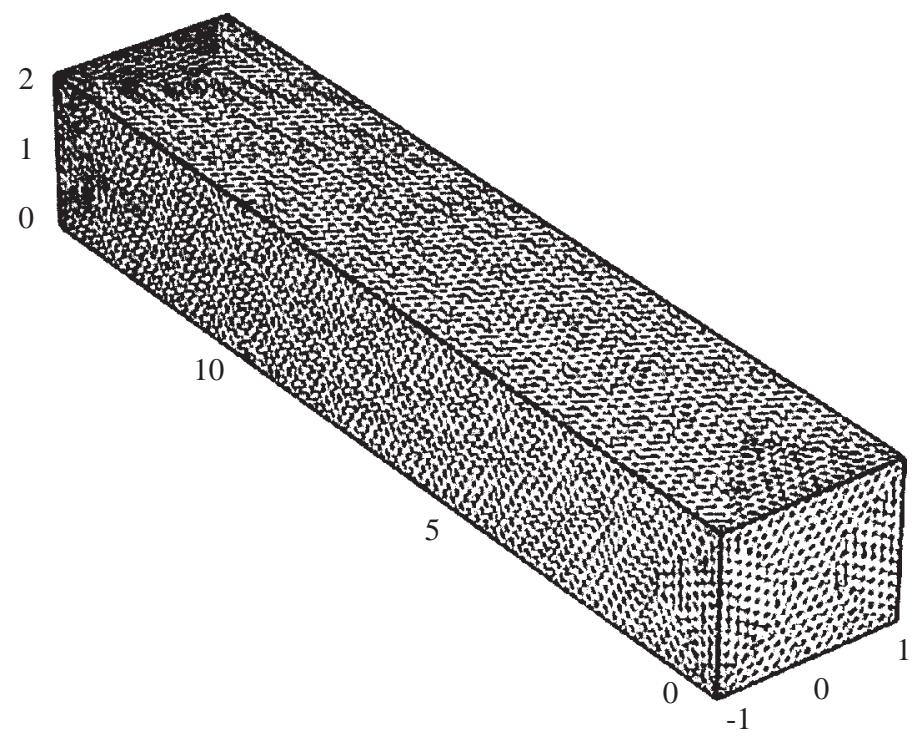

FIGURE 3. Schematic view of meshing
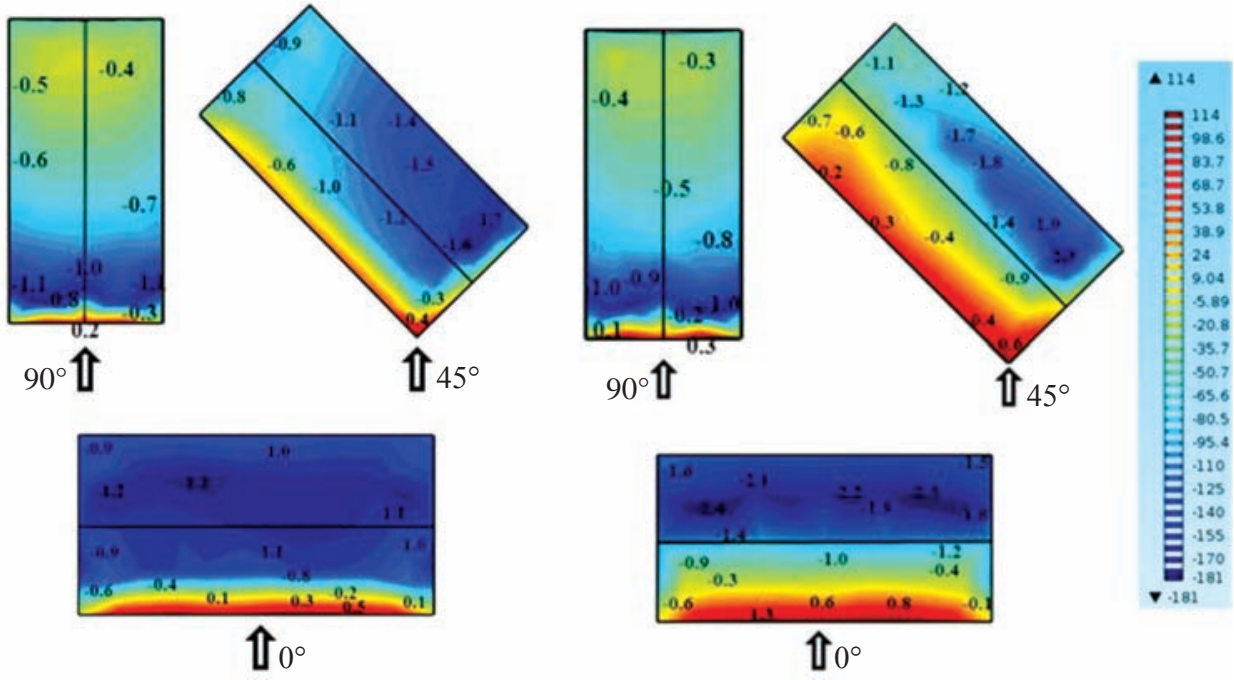

(b) Gable roof pitch $25^{\circ}$

(a) Gable roof pitch $10^{\circ}$

FIGURE 4. Plan view of pressure coefficient, $C_{p}$ distributions over two gable roofs when imposed with wind in directions of $0^{\circ}, 45^{\circ}$ and $90^{\circ}$ 
highest suction on the leeward surface. While in the $90^{\circ}$ of wind direction, the suction pressure decrease with the increase of distance to the leading edge of the roof. From this figures, it show that most of the failure on gable roof occurs at the roof ridge, the leading and the corner of the roof. The detail values of maximum pressure coefficient of the gable roof are tabulated in Table 1.

Based on Xiao and Yuan (2013) for majority of the lowrise buildings with larger rigidity, the fluctuating of wind pressures on buildings are mainly derived from two factors: (1) natural turbulence or gustiness in the free stream flow and (2) unsteady flow generated by the body itself, by the phenomena such as separations, reattachments and vortex shedding. Fluctuating wind pressures are mainly generated by the first factor for no separations on the windward region. While fluctuating of wind pressures on the leading edges of the roof, the roof ridge and the leading edges of the longitudinal walls are mainly generated by the second factor.

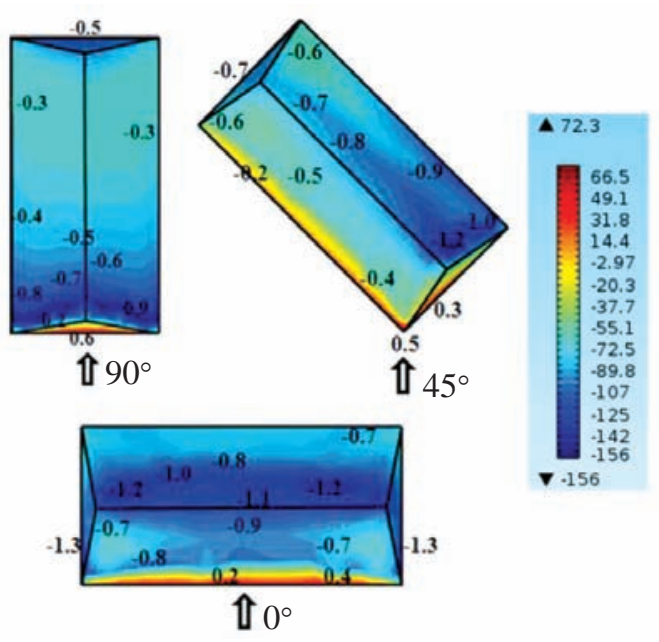

(a) Hip roof pitch $10^{\circ}$
HIP ROOF

While Figure 5(a) and (b) show the pressure distribution of hip roofs pitch of $10^{\circ}$ and $25^{\circ}$. The locations of peak pressure for pitch $10^{\circ}$ and $25^{\circ}$ of the hip roof is quite nearer to each other. The difference between this is the increasing value of $C_{p}$. The value of $C_{p}$ for hip roof of $25^{\circ}$ is much higher than hip roof of $10^{\circ}$.

The findings of Goliber (2009) have stated that the critical pressure on the hip roof is close to the corner, ridge, and the leading or sides of low-rise building. The cause of this is due to the flow separation and vortex formation in which is capable in producing large suction pressure (negative $C_{p}$ ) nearer to upstream corner (Xinzhong \& Nan 2007, Tieleman 2003). Therefore based from these simulation results, the findings is in line and acceptable with the statement from other researches. The contour colour which represents the pressure coefficient distribution values have shown to concentrate at that area as can be observed in Figure 4. All of these maximum values of pressure coefficient are tabulated in Table 1.

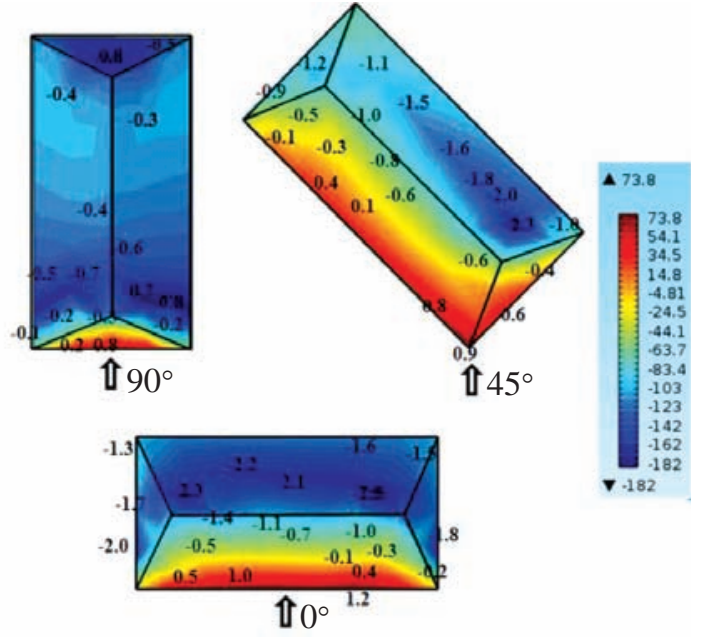

(b) Hip roof pitch $25^{\circ}$

FIGURE 5. Plan view of pressure coefficient, $C_{p}$ distributions over two hip roofs when imposed with wind in direction of $0^{\circ}, 45^{\circ}$ and $90^{\circ}$

TABLE 1. The values of Cp for both roofs

\begin{tabular}{|c|c|c|c|c|c|c|c|}
\hline \multirow{3}{*}{$\begin{array}{c}\text { Types of } \\
\text { roof }\end{array}$} & \multirow{3}{*}{$\begin{array}{c}\text { Roof } \\
\text { pitch }\left(^{\circ}\right)\end{array}$} & \multicolumn{6}{|c|}{ Wind Direction $\left(^{\circ}\right)$} \\
\hline & & \multicolumn{2}{|c|}{0} & \multicolumn{2}{|c|}{45} & \multicolumn{2}{|c|}{90} \\
\hline & & $C_{P \max ,+v e}$ & $C_{P \max ,-v e}$ & $C_{P \max ,+v e}$ & $C_{\text {Pmax,-ve }}$ & $C_{P \max ,+t v e}$ & $C_{\text {Pmax }, \text { tve }}$ \\
\hline \multirow[t]{2}{*}{ Gabel } & 10 & 0.5 & -1.2 & 0.4 & -1.7 & 0.2 & -1.1 \\
\hline & 25 & 1.3 & -2.4 & 0.6 & -2.3 & 0.3 & -1.0 \\
\hline \multirow[t]{2}{*}{ Hip } & 10 & 0.4 & -1.3 & 0.5 & -1.2 & 0.6 & -0.9 \\
\hline & 25 & 1.2 & -2.5 & 0.9 & -2.3 & 0.8 & -0.8 \\
\hline
\end{tabular}

EFFECT OF WIND DIRECTION

Generally, the wind flow comes from various directions. Therefore, all possibilities of wind direction should be studied in order to determine its effect on different type of roof. The maximum damage on the roof surface has proved to depend on the wind direction particularly when it is subjected to 
extreme winds. Based on the first parametric analysis, all the building models have the biggest failure when the wind flow in the direction of $0^{\circ}$.This is due to the maximum area of the leeward surface in this wind direction. High suction pressure is obtained on the roof area simultaneously.

In the $45^{\circ}$ of wind direction, both of the gable and hip roofs with roof pitch of $25^{\circ}$ had experienced the highest suction (negative $C_{p}$ ) than the roof with smaller roof pitch. The same condition also happened in the wind direction of $90^{\circ}$ for the hip roof. However different condition was obtained by gable roof when it is subjected to the same wind direction. Both of gable roof with different roof pitch was not affected significantly. This is due to the gable roof pitch which is parallel to the wind direction when the wind flows in $0^{\circ}$ as stated by $\mathrm{Xu}$ and Reardon (1998).

\section{EFFECT OF ROOF PITCH}

The next parametric study is on the roof pitch. Two different roof pitches will be compared in this section which is $10^{\circ}$ and $25^{\circ}$. Xu and Reardon (1998) stated that with the increase of roof pitch, the mean suctions become relatively uniform distributed over the leeward roof slope. The mean suctions, however, significantly decrease on the windward roof slope and moderately increase on the side roof slope. Based on this case, 9 locations have been plotted randomly in the area of windward, side face (slopes) and leeward surface of hip roof as shown in Figure 6(a).

It is proved that the $C$ values in windward is decreasing from location 1 to 5 which is nearer to roof ridge either for roof pitch $10^{\circ}$ or $25^{\circ}$. The $C_{p}$ values keep decreasing at the two side faces (side slopes) which create high suction pressure at that area. Whilst on the leeward surface, the hip roof pitch of $25^{\circ}$ shown to have significantly uniform distributed pressure whilst the hip roof pitch $10^{\circ}$ had some increment. It can be concluded that this findings are in line with $\mathrm{Xu}$ and Reardon (1998) results. Another comparison for gable roof is shown in Figure 6(b), which indicate that the lower the roof pitch, the smaller the pressure will be experienced by the surface of the roof due to the extreme wind.

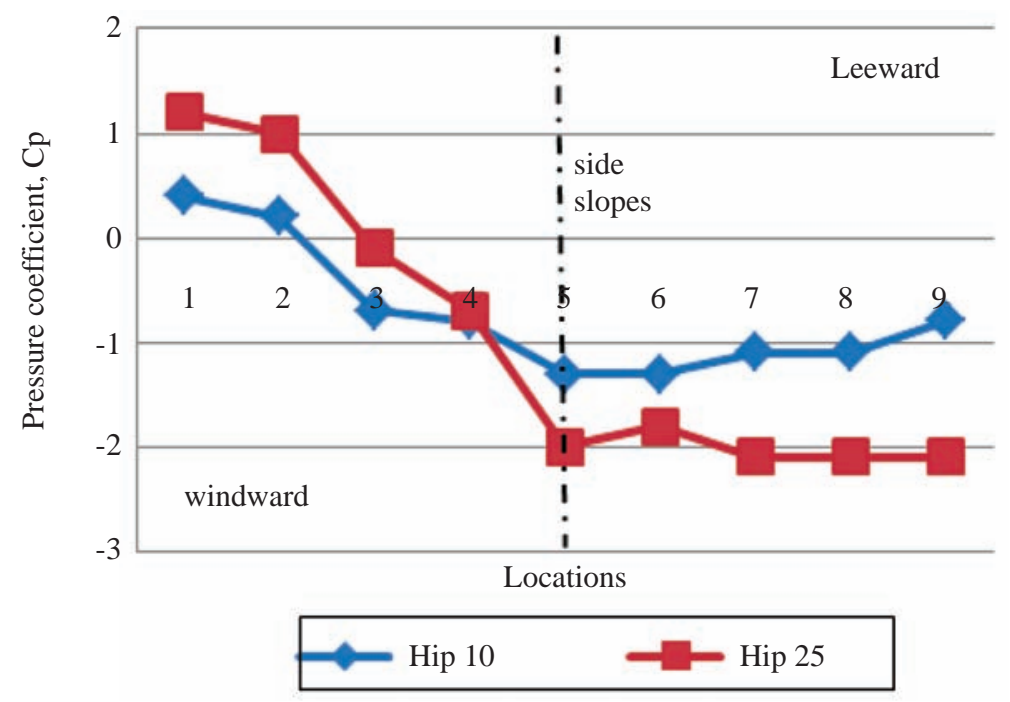

(a) Hip roof

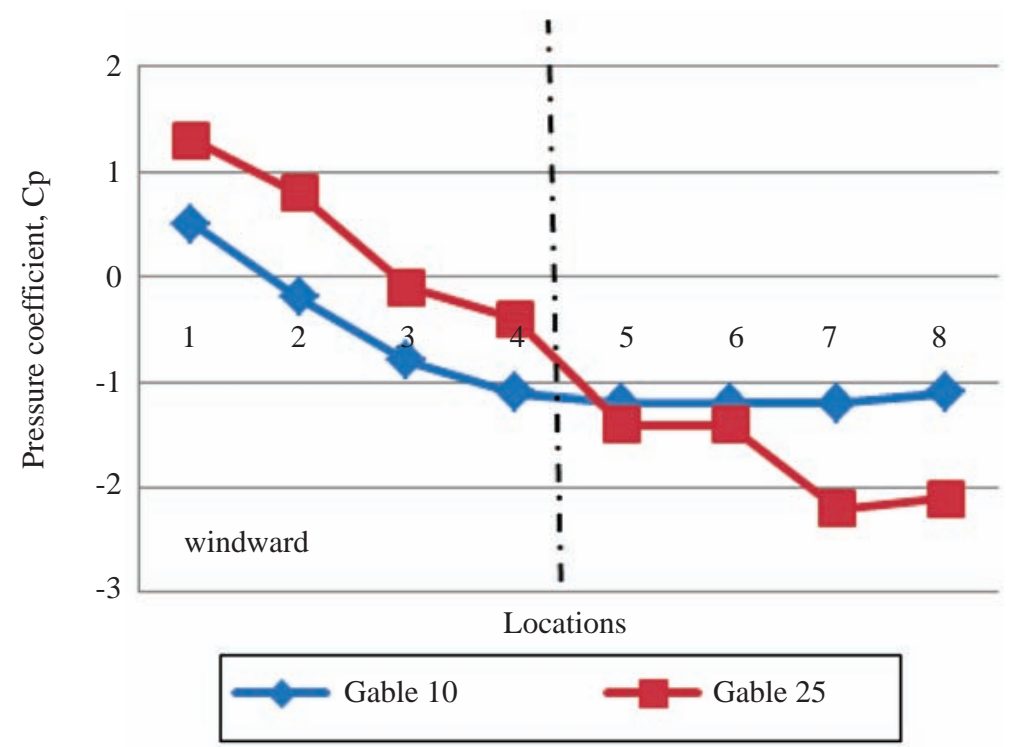

(b) Gable roof

FIGURE 6. The pressure coefficient on the selected point for both types of roofs 
EFFECT OF ROOF TYPES

The last parametric study is the comparison on the effect of different roof types with the same roof pitch. As the main objective in this study is to find the most practical and less damage roof design, the roof pitch of $25^{\circ}$ will not been considered in this discussion. Therefore, this section will only discuss the comparison between gable and hip roofs pitch of $10^{\circ}$. In the $0^{\circ}$ of wind direction, it can be seen in Figure 4(a) and Figure 5(a), the contours of the worst negative pressure coefficient is on the downwind slopes of the gable roof pitch of $10^{\circ}$ compared to hip roof pitch $10^{\circ}$.

Whereas in the $45^{\circ}$ of wind direction, in which the wind direction oblique to roof ridge, both of the roofs experience peak wind pressures on the same location which at the leading edges on left side of the roof. The pressures coefficient values at this location were found to be -1.7 and as low as -1.2 for gable and hip roof respectively. It can be seen that the pressure distribution on the hip roof is much lower than the gable roof. The same situation also occurred in the $90^{\circ}$ of wind direction. As overall, it showed that the hip roof pitch of $10^{\circ}$ is more practical than the other model in this study.

\section{CONCLUSIONS}

The locations of maximum pressure distribution on the roof when subjected to wind extreme have been identified. Most of the damage or failure of the roof system is caused by high suction pressure. The following conclusions are the finding from the study.

1. For gable and hip roof pitch of $10^{\circ}$ and $25^{\circ}$, the biggest failure occurs on the wind direction of $0^{\circ}$ at the area of leeward face. This is due to the bigger area (maximum area) in this wind direction.

2. The study of Xu and Reardon (1998) are in line with the results from this study which states that with the increase of hip roof pitch, the mean suctions become relatively uniformly distributed over the leeward roof slope. The mean suctions, however, significantly decrease on the windward roof slope and moderately increase on the two side roof slopes.

3. With the increase of roof pitch will increase the distribution of pressure over the roof surface caused by extreme wind.

4. The hip roof with pitch of $10^{\circ}$ is more practical and less damaged compare to other model in the study.

$$
\text { ACKNOWLEDGEMENT }
$$

The authors wish to thank Universiti Kebangsaan Malaysia for the research grant DLP-2013-027 and AP-2015-011.

REFERENCES

Goliber, M.R. 2009. Pressure Distribution on the Roof of a Model Low-Rise Building Tested in a Boundary Layer
Wind Tunnel. Master Thesis, University of Iowa State, USA.

Osman, S. A., Khalim, A., Rashid, A. \& Majid, T. 2004. Numerical prediction of wind loading on concrete buildings. Proceeding of $7^{\text {th }}$ International Conference on Concrete Technology in Developing Countries: 123-132.

Osman, S. A., Khalim, A., Rashid, A., Majid, T. \& Choon, K. E. 2006. Aplikasi Kaedah Unsur Terhingga Secara Dua Dimensi dalam Kejuruteraan Angin. Jurnal Kejuruteraan: 85-96.

Manwell, J., McGowan, J. \& Rogers, A. 2002. Wind Energy Explained Theory,Design and Application. John Wiley \& Sons, LTD.

Nur Zuleikha Baha. 2015. Kesan Angin Ekstrim Kepada Struktur Bumbung Bangunan Beraras Rendah. BSc Thesis, Universiti Kebangsaan Malaysia.

Rahaman, S. 2007. Permodelan Taburan Tekanan Angin Ekstrem Bagi Struktur Bumbung di Rumah Kediaman. BSc Thesis, Universiti Kebangsaan Malaysia.

Ramli, N. I., Majid, T. A., Ali, M. I., Saad, H. S. M., Hashim, M. \& Zakaria, I. 2010. Wind Related Disaster Risk Reduction Activities in Malaysia. Malaysia Country Report IG WRDRR Joint workshop.

Selvam, R.P. 1992. Computation of Pressure on Texas Technical Building. Journal of Wind Engineering and Industrial Aerodynamics 41-44: 1619-1627.

Simiu, E. \& Scanlan, H. 1978. Wind Effects on Structures. John Wiley \& Sons.

Tieleman, H.W. 2003. Wind tunnel simulation of wind loading on low-rise structures: a review. Journal of Wind Eng. and Industrial Aerodynamics 91: 1627-1649.

Xu, Y. \& Reardon, G. 1998. Variation of Wind Pressure on Hip Roofs with Roof Pitch. Journal of Wind Engineering and Industrial Aerodynamics 73: 267-284.

Xiao-kun Jing \& Yuan-qi Li. 2013. Wind tunnel tests for wind pressure distribution on gable roof buildings. The Scientific World Journal. 396936. doi:10.1155/2013/396936

Xinzhong, C. \& Nan, Z. 2007. Equivalent static wind loads on low-rise buildings based on full-scale pressure measurements. Engineering Structures 29: 2563-2575.

Nuur Zuleikha Baha

Siti Aminah Osman*

Structures, Materials and Construction Management Research Group

Department of Civil \& Structural Engineering

Universiti Kebangsaan Malaysia

43600 UKM Bangi, Selangor

Malaysia

*Corresponding author

Phone: +603 - 89218362

Email address: saminah@ukm.edu.my 